\title{
A VALLOMÁSOK IGAZSÁGTARTAMÁT MEGHAMISÍTÓK TÍPUSAI ÉS VIZSGÁLATUK KIHALLGATÁSI HELYZETBEN 2. rész, Az elhallgató
}

\author{
Czabán Csaba ${ }^{1}$, Alpek Alex², Bártfai Anna ${ }^{3}$, Kertesy Andrea \\ Iványuk Áron ${ }^{5}$, Benczúr Lilla ${ }^{6}$, Takács Szabolcs ${ }^{7}$, Kis György ${ }^{8}$ \\ ${ }^{1}$ ANIMA Polygraph Kft, pszichológus, PhD hallgató, \\ 3,4,5 Károli Gáspár Református Egyetem, Pszichológia Intézet, hallgató, \\ ${ }^{6}$ klinikai szakpszichológus, \\ ${ }^{7}$ Károli Gáspár Református Egyetem, Pszichológia Intézet, egyetemi adjunktus, \\ ${ }^{8}$ ANIMA Polygraph Kft, Ügyvezető
}

\begin{abstract}
Absztrakt
Cikksorozatunkban annak a kutatómunkának az eredményiről számolunk be, amelyet 2014-ben kezdtünk és összefoglalóját (Kis és társai, 2017) cikkünkben tettünk közzé. Jelen cikkünk témája a hazugságtípusok elhallgató típusa lesz. Arra kerestük a válaszokat, hogy az elhallgatók elbeszéléseinek hanganyagai mely területeken különböznek a hazugok másik típusától (meghamisító). Valamint azt is megvizsgáltuk, hogy más elbeszélésektől, azok hanganyagától mely pontokon tudjuk megkülönböztetni őket. Vizsgálatainkból kiderült, hogy számos ponton fedezhetők fel eltérések mind a meghamisítóktól, mind pedig más történetek hanganyagaitól. Az elhallgatók (annak ellenére, hogy a történet bizonyos részeiről szisztematikusan nem beszélnek) más paraméterek esetében mutatnak jellegzetességeket mind például azok, akik a történet egyes részeit elferdítik, meghamisítják.
\end{abstract}

Kulcsszavak: hazugság • LVA • hangelemzés • tanúvallomás • elhallgatás

A kutatási engedély száma 278/2016/P. A vizsgálatban résztvevő összes vizsgálati alany írásban hozzájárult a hanganyagok és videóanyagok további kutatásokban és tudományos publikációkban való felhasználásához.

\begin{abstract}
We report about the results of a research work in these series of articles, which was launched in 2014 and it's summary is published in our article (Kis et. at. 2017). In this article we are going to discuss accomplice as the second figure of the typology of lies. We were looking for differences in speech segments between accomplices' and falsifiers' narratives. We examined certain aspects of other narratives and audio files for defining further distinctions. Our research showed numerous points where the narratives coming from the accomplice differs from falsifiers' and others' narrative audio segments. The accomplice (despite of not telling certain details systematically) shows particular
\end{abstract}


characteristics in other parameters compared to those who are suggesting different details instead or faking details.

Keywords: lie • LVA • speech analysis • deposition • accomplice

Research license 278/2016/P. All participants signed a written document in which they declared: all audio and video records can be used for further researches and academic publications.

\section{BEVEZETŐ}

A hazugságkutatók - bár többféle, olykor egymástól jelentősen eltérő megállapításokra jutnak - jórészt egyetértenek abban, hogy hazugságról akkor beszélhetünk, ha

- a hazugnak szándékában áll a megtévesztést elkövetni, tehát tudatosan igyekszik a valós tényektől eltérő információkat átadni a fogadó félnek;

- a hazug számára tétet jelent e szándék sikerre vitele: vagy valamilyen, számára negatív következményt (pl. büntetést) kerül el vele, vagy közvetlen nyeresége származik a megtévesztésből;

- a hazug tudja, hogy kockázatot vállal megtévesztő cselekedetével.

Kísérleteinkben három hazug típust (meghamisító, elhallgató, titkoló), valamint egy „státusváltó” típust (patetikus) vizsgáltunk. Jelen cikkünk az elhallgató típusra fókuszáló kísérleti eredményekről számol be.

A szakirodalomban Ekman (2009) az itt tárgyalt elhallgató típust leplezőnek nevezi. Az elhallgató a kihallgatási helyzetben bizonyos információkat visszatart anélkül, hogy bármi igaztalanságot adna elő.

Mindennapi életünkben találkozhatunk az elhallgatással, ami nem minden esetben hazugság. Ezekben az esetekben felhatalmazást kapunk arra, hogy valamit elhallgassunk. Ilyen eset lehet, ha a párunknak születésnapi ajándékot szándékozunk vásárolni, ezért annak beszerzésére jelentős időt fordítunk, de azt nem közöljük a párunkkal, hogy az adott időpontban mivel voltunk elfoglalva, elhallgatjuk, hogy az ajándék felkutatásával és vásárlásával voltunk elfoglalva. Igaz, hogy többnyire kérdések sem hangzanak el... Az elhallgatást a bűnügyekben a gyanúsítottak és a bíróságokon a vádlottak szívesen választják. Nem kell kitalálni egy történetet, amit a hazug igaznak ad elö, inkább elhallgatja a releváns információkat. Ezekben az esetekben a hazugnak nem kell állandóan figyelemmel kísérni, hogy korábban milyen vallomást tett, mert nem mondta el azokat a tényszerú adatokat, amire a kihallgatója kíváncsi lenne. Az elhallgatás a tanúk esetében is előfordul, annak ellenére, hogy a hatóság figyelmezteti a hamis tanúzás következményeire. Az elhallgatás nem jár magas kognitív erőfeszí- 
téssel és érzelmileg is kevésbé megterhelő, mint a meghamisítás (Czabán és társai, 2017a). Az elhallgató lényegesen kisebb kockázatot vállal, mint a meghamisító. Később is - mikor szembesítik az elhallgatás tényével - több hivatkozási lehetősége van arra, hogy miért hallgatta el a releváns információkat. Ilyen például az a hétköznapi jelenség, hogy elfelejtünk neveket, nem emlékszünk pontosan időpontokra, bizonytalanok vagyunk események pontos történéseit illetően. Ez a mindennapi tapasztalat jó védekezési stratégiát biztosít az elhallgatónak, amitől beazonosítása nehézzé válik.

Mindez nem jelenti azt, hogy az elhallgató nem fog hazugságjeleket mutatni egy jól megtervezett kihallgatáson. Ennek igazolásához segítségül hívtuk az LVA hangelemzési technológiát, ami képes jól azonosítani a hazug érzelmeinek elemzésével az elhallgatást. Például a magas S.O.S. jelzés; Say or Stop („mondjam, vagy hallgassak”), azt jelzi az LVA hangelemzési technológia alkalmazásánál, hogy a kihallgatott tudatosan nem fed fel minden információt a feltett kérdéssel kapcsolatban, vagy bánja, hogy megadta azt. Ha ez az LVA üzenet a releváns kérdésnél mutatkozik akkor feltételezhetjük, hogy elhallgatásról van szó. Ugyanakkor óvatosan kell értelmezni a jelzést, mivel nem biztos, hogy szándékos elhallgatásról van szó. Lehetséges az is, hogy a tanú nem tartja fontosnak az általa birtokolt információt, azt elhallgatja a hazugság szándéka nélkül, de az LVA bejelez. Ilyen esetekben tovább kell kérdezni a tanút, bíztatni kell, hogy minden információt mondjon el, ne ő válogasson, hogy mi fontos és mi nem.

A kutatási összefoglalóban (Kis és társai, 2017) részletesen bemutattuk a maffiajátékot, valamint annak szerepeit. Az elhallgató típust a maffiajáték során a kollaboránsok képviselik. Esetükben arról van tehát szó, hogy olyan információt tartanak vissza, melyek relevánsak lehetnek az adott vallomás során a vizsgálat tárgyában. Ezt az információt azonban valamilyen indokok alapján viszszatartják, nem osztják meg a kihallgatóval. A maffiajátékban a kollaboráns az a polgár volt, aki tudta, hogy kik a maffiatagok - de maga is áldozatukká válhatott. Mégis, akkor nyerte meg a játékot, ha a maffiatagok nyertesként kerültek ki belőle, tehát mindent el kellett követnie, hogy a kezükre játsszon. Ez az áruló szerepkör azonban igen megterhelő tud lenni - fóként úgy, hogy a maffiatagok nem ismerik a kilétét, tehát nem fogják védelmezni! A külön instrukciók során nekik is titkolniuk kellett kilétüket a kihallgatók előtt, tehát az éjszakára vonatkozó kérdések során (a kollaboráns az első éjszaka során ébren van, tehát látja a maffiatagokat, így tudja, hogy kik ôk) el kellett hallgatniuk azt, hogy az első éjszakán ők ennek az információnak a birtokába jutottak.

Egy gyakorlati esettel megvilágítva: emberölési ügyben a rendőrhatóság több tanút is kihallgatott, de a nyomozás nem vezetett eredményre, az ügyet lezárták. Néhány év múlva egy új információ birtokában ismételten megnyitották az aktát és már LVA felhasználásával hallgatták meg a tanúkat. Az LVA 6.50 offli- 
ne alkalmazással ${ }^{1}$ a hangelemző technológia több válasznál is S.O.S. jelzést adott, amit a nyomozók a verbális tartalom elemzésével értékeltek. Az előadott vallomást kontextusba helyezve arra a következtetésre jutottak, hogy a tanú nem mondott el mindent, elhallgatott fontos információkat. Az ismételt meghallgatáson kiderült, hogy a tanú a nyomozás szempontjából fontos információt nem gondolta olyannak, amit meg kell osztania a hatósággal, maga döntötte el, hogy az nem fontos. A nyomozóknak sikerült a tanú által nem fontosnak gondolt információkat is megszerezniük, ami újabb lendületet adott a nyomozásnak. A további kihallgatásoknál is az LVA technológiát használták és az egyik gyanúsítotti kihallgatáson hasonló helyzettel találkoztak. A gyanúsított elhallgatta, hogy az emberölésről milyen forrásból származott az az információ, ami pontos ismeretet jelentett az elkövetés módjáról. A gyanúsított azt hallgatta el, hogy egy beszélgetést hallott az élettársa és annak barátja között, akik éppen az emberölést beszélték meg. Az említett gyanúsított ebből a forrásból tudta, hogy mi történt valójában, ezt elhallgatta, a poligráf vizsgálat pedig azt az eredményt adta, hogy pontos ismeretei vannak az elkövetés módjáról. Amennyiben ezt a beszélgetést nem hallgatta volna el a nyomozók elől, akkor nem ő lett volna az ügy első számú gyanúsítottja.

\section{AZ ELHALLGATÓ TÍPUS JELLEGZETESSÉGEINEK ISMERTETÉSE A HANGELEMZÉS ALAPJÁN}

Jelen cikkben az elhallgatók (maffiajátékban a kollaboránsok) sajátosságait mutatjuk be. Az adatok feldolgozását ugyanúgy végeztük el, mint azt az első részben láttuk (Czabán és társai, 2017a). Az eredmények matematikai feldolgozásának alapját lásd e tematikus szám Takács és társai által jegyzett cikkében. A típusok összehasonlítására egy bootstrap eljárással kombinált varianciaanalízist alkalmaztunk (a bootstrap eljárást más pszichológiai vizsgálatokban is sikeresen lehet alkalmazni, lásd Marcinko et al., 2013). Bár az LVA paraméterekre a normalitás nem teljesült (Kolmogorov-Smirnov tesztet alkalmazva minden változó esetében SIG<0,001 adódott), a bootstrap eljárás segítségével a csoportok közvetlen hibáját határoztuk meg - így a csoportok egymással összehasonlíthatókká váltak (Efron és Gong, 1983). A bootstrap eljáráshoz IBM SPSS 23.0 programcsomagot használtunk.

A normalitás hiánya miatt a varianciaanalízist rangvarianciaanalízis alkalmazásával is ellenőriztük (Kruskal-Wallis tesztet, illetve rang-Welch-próbát végeztünk), a páros összehasonlításokhoz pedig Bonferroni korrekcióval elvégzett Brunner-Munzel (BM) tesztet használtunk. A sztochasztikus homogenitás-vizsgálatokhoz (lásd Vargha, 2005) a ROPstat programcsomagot használtuk. Miként

Nem „itt és most” technológiával, hanem utólagos elemzést alkalmazva, miként mi is tesszük azt a kísérleti helyzetünkből származó adatok elemzésekor. 
az első részben (Czabán és társai, 2017a), úgy most is csak a sztochasztikus dominancia adatait mutatjuk be, az ott már ismertetett okokból.

\section{1. táblázat}

Tipológiai sajátosságok - sztochasztikus dominancia mértéke az egyes paraméterek mentén

\begin{tabular}{|c|c|c|c|c|c|}
\hline & Dominancia & BM & szabadsági fok & $\mathbf{p}$ & korrigált $p$ \\
\hline Érzelmi szint & 0,612 & 4,43 & 197,2 & 0 & $0,0001^{* * *}$ \\
\hline Kognitív szint & 0,393 & $-4,42$ & 202,8 & 0 & $0,0001^{* * *}$ \\
\hline Stressz szint & 0,369 & $-5,4$ & 205 & 0 & $0,0000^{* * *}$ \\
\hline Gondolkodási szint & 0,338 & $-6,26$ & 191,4 & 0 & $0,0000^{* * *}$ \\
\hline Közlési hajlandóság hiánya & 0,516 & 0,73 & 225,5 & 0,4664 & 1 \\
\hline Koncentráció & 0,446 & $-2,53$ & 232,1 & 0,0121 & $0,0607+$ \\
\hline Párhuzamos gondolatok & 0,522 & 0,98 & 217,8 & 0,329 & 1 \\
\hline Egyenletesség & 0,601 & 4,33 & 210,5 & 0 & $0,0001^{* * *}$ \\
\hline Zavarodottság & 0,548 & 2,12 & 217,6 & 0,035 & 0,1752 \\
\hline Hazugság stressz & 0,431 & $-2,79$ & 203,7 & 0,0057 & $0,0287^{*}$ \\
\hline Hazugság valószínűség & 0,52 & 0,92 & 226,8 & 0,3561 & 1 \\
\hline Kognitív szint & 0,481 & $-0,76$ & 203,4 & 0,4485 & 1 \\
\hline Globális stressz & 0,399 & $-4,08$ & 204,6 & 0,0001 & $0,0003^{* * *}$ \\
\hline Téma elutasítottsága & 0,545 & 2 & 221,8 & 0,0465 & 0,2325 \\
\hline Reakcióra való várakozás & 0,675 & 8,02 & 211 & 0 & $0,0000^{* * *}$ \\
\hline Gondolkodási arány & 0,429 & $-3,16$ & 219,7 & 0,0018 & $0,0091^{* *}$ \\
\hline Tudat alatti megismerési szint & 0,471 & $-1,46$ & 262,3 & 0,1447 & 0,7235 \\
\hline Elfojtott érzelmi szint & 0,547 & 2,12 & 226 & 0,0352 & 0,1762 \\
\hline Képzelet, fantázia & 0,402 & $-3,7$ & 193,8 & 0,0003 & $0,0014^{* *}$ \\
\hline
\end{tabular}

Vizsgáljuk meg, hogy az elhallgatók esetében mely paraméterek mutatnak szignifikánsan magas, illetve alacsony értékeket és ezek összességében milyen tipológiai sajátosságokra utalhatnak.

Az elhallgató a tettesekkel van, de tevőlegesen nem tud részt venni az éjszakai eseményekben, és az elkövetők sem tudják, hogy velük szimpatizál, velük dolgozik. Szignifikánsan magas értékei az alábbiakban jelentkeznek: érzelmi szint, egyenletesség és reakciókra való várakozás. Tehát esetében azt figyelhet- 
jük meg, hogy a helyzet érzelmileg megterhelőbb, mely a játék sajátosságából és a kollaboráns szerepéből fakad. ${ }^{2}$

- Egyenletesség: bizonyos témakörökről szívesen beszél, szívesen oszt meg információkat, míg más esetekben csöndesebbé válik, nem szívesen ad át információt. Ezt a fajta kettősséget lehet érzékelni az egyenletesség magasabb értékében (tehát az egyenletességben való „eltérésben”, egyenetlenségben).

- Várakozás reakciókra: a kihallgató reakcióra való fokozottabb várakozás éppen az elhallgatás okán jelentkezik. Dilemmáját így is fogalmazhatnánk: „Eleget mondtam-e már, tovább léphetünk-e?”, avagy „Mondjam, vagy hallgassak?”.

A szignifikánsan alacsony értékek a magasakhoz képest lényegesen több ponton jelennek meg, azonban alapjában véve egyetlen okra vezethetők vissza, a következők szerint: a gondolkodási szint alacsony értéke, a stressz szint alacsonyabb értéke, a képzelet és a kognitív erőfeszítések alacsony mivolta mind azt jelzi, hogy az elhallgató a hazugság „könnyebb útján jár” - nem kell pontosan visszaemlékeznie dolgokra, egyszerüen csak el kell hallgatnia részleteket. Nem kell új dolgokat kitalálni, nincsen elfedés - pusztán kihagyja az információkat.

Összességében tehát elmondható, hogy az elhallgatónál, a meghamisítóhoz viszonyítva (lásd Czabán és társai, 2017a), lényegesen több ponton tetten érhetőek az eltérések az elhallgató csoport elbeszéléseinek paramétereiben.

\section{DISZKUSSZIÓ}

A kutatás során nyert eredményeket elemezve azt kaptuk, amire a hipotézisünk során számítottunk. Az elhallgató a könnyebb utat választja, az elhallgatásának nincs akkora kockázata, mint a meghamisítónak, nem kell állandóan a memóriájára hagyatkoznia, így viselkedése nem jár kognitív erőfeszítéssel. A fentebb említett konkrét példa azonban megmutatta, hogy az elhallgató is többnyire kontrollálja magát, amennyiben szándékosan hallgatja el a releváns információkat. Figyel arra, hogy kontrollálja mit és mennyit ad át a vallomása során. A tapasztaltabbak szívesen beszélnek a konkrét ügy kapcsán azokról a helyzetekről, amit a nyomozóhatóság már tud, de elhallgat olyan információt, amit úgy véli, a hatóságnak még nincs a birtokában a bizonyításhoz. Sokat és összefüggően beszél azokról, ami igaz, de megakad az előadása akkor, ha olyan kérdést kap, amiről nem szeretne beszélni, inkább elhallgatja a birtokában lévő információt, mert az gyanúba keverné. Ilyen helyzetekben a nyomozónak ala-

$2 \quad$ Megjegyezzük, hogy a kísérleti helyzetben az elhallgató olyan szerepbe került, melyben neki úgy kellett segítenie a maffiatagokat, hogy közben ő maga is az áldozatukká válhatott. Ez a fajta kiszolgáltatottság megjelenhetett például az érzelmi szint magasabb értékeiben. 
posan elemezni kell a verbális stílust és a verbális tartalmat. Bemutattuk, hogy az elhallgatás kontroll alatt tartása kimutatható az LVA hangelemzési technológia használatával.

Miként Ekman fogalmaz (Ekman, 2009): a leplezés a hazugság könnyebb útja. Láthattuk az első tanulmány eredményeiben (Kis és társai, 2017a), hogy a meghamisítás nagyfokú kognitív terheléssel jár. Ezzel szemben az elhallgató esetében két komolyabb megfigyelést is tehettünk:

- Megemelkedett, kiemelkedő volt az érzelmi szintje (lényegében a kísérlet során másokon múlik a sorsa, ôt magát is kiszavazhatják a maffiatagok), illetve a kihallgatás során folyamatosan vár a kihallgató reakciójára és egyenetlen a beszéde: egyes témákban szívesen oszt meg információkat, máshol pedig ennek ellenkezőjét tapasztaljuk.

- Ezzel szemben Ekman (2009) eredményeihez hasonlóan, a gyengébb kognitív terhelés irányába mozdul: alacsonyabb stressz szint (ő nem tehet semmiről), alacsonyabb gondolkodási arány és képzelet (csak elhallgatni kell, nem új dolgot kitalálni), ami mind azt mutatja, hogy lényegesen kisebb erőfeszítésbe kerül számára ez, mint akár azoknak, akiknek pontosan kellene felidézni a játék eseményeit.

\section{Külön is kiemelendő sikerként értékelhetjük, hogy az elhallgató ti- pológiájánál a szakirodalmi tapasztalatokkal összhangban lévő ered- ményt kaptunk a hangelemzés alkalmazásával.}

Mindez annak tükrében különösen fontos eredmény, hogy egy egyetemi kísérlet, lényegében játék helyzeten sikerült olyan tétet (a játék örömre, a győzelemre való törekvés) létrehoznunk, melynek kulcsszerepe van abban, hogy a hangelemzés megfelelően kerüljön alkalmazásra.

\section{KITEKINTÉS, ÖSSZEGZÉS}

A kísérleti helyzetet összegezve elmondhatjuk, hogy pozitív eredményt mutató típus esetében (elhallgató) a szakirodalommal összhangban (Ekman, 2009) lévő eredményeket kaptunk - ráadásul úgy, hogy az együttesen számított paraméterek jelentős részében eltéréseket, kiemelkedő, vagy éppen igen alacsony értékeket tapasztaltunk.

Az elhallgató esetében igazolni tudtuk, hogy összességében egy „olcsóbb”, kevésbé megterhelő hazugság típussal állunk szemben, ahol kevésbé fárad a hazugságot elkövető akkor, ha elhallgatja a kihallgató elől az információkat - cserébe viszont a hangjában megjelenő egyenetlenségek, elképzelések és gondolkodási faktorok, kognitív erőfeszítések (visszaemlékezés) hiánya árulójává válhatnak.

A kísérletek további részében fontos szempont volt számunkra az, hogy a videóelemzésekkel összefüggésben (Kis és társai, 2017e), illetve az egyéb tapasz- 
talatok, szakértői meglátások mellett igazolni tudjuk azt, hogy az elhallgató esetében például a lelkiismeret-furdalás, mint jelenség megjelenik-e, tetten érhető-e? Természetesen ezeket a jelenségeket - minthogy nem feltétlenül „pillanatnyi ideig fennállók" - nem az itt és most technikák segítségével tudjuk tetten érni, hanem éppen azzal, hogy hosszabb ideig tartó megfigyelések segítségével igyekszünk azt kimutatni, hogy valaki egy történet bizonyos részeinek elmondásakor melyik típushoz (meghamisító, elhallgató, igazat mondó) tartozik.

\section{BIBLIOGRÁFIA}

Efron, B. \& Gong, G. (1983.) A Leisurely Look at the Bootstrap, the Jackknife, and Cross-Validation. The American Statistician, 37(1), 36-48.

Ekman, P. (2009.) Beszédes hazugságok: A megtévesztés árulkodó jelei a politikában, az üzletben és a házasságban. Budapest: Kelly Kiadó Kft.

Marcinko, D., Jaksic, N., Ivezic, E., Skocic, M., Surányi, Zs., Loncar, M., Francic, T., Jakovljevic, M. (2013): Pathological Narcissism and Depressive Symptoms in Psychiatric Outpatients: Mediating Role of Dysfunctional Attitudes, Journal of Clinical Psychology, 70(4), 341-352.

Vargha A. (2005.) Sokaságok összehasonlítása új módszerekkel. Statisztikai Szemle 83, 429-448.

\section{Tematikus szám hivatkozott cikkei}

Kis Gy., Takács Sz., Liberman A., \& Benczúr L. (2017.): A megtévesztés tipológiája - összefoglaló tanulmány. Psychologia Hungarica Caroliensis, 4(2), 2016. pp. 7-26.

Czabán Cs., Alpek A., Bártfai A., Kertesy A.; Iványuk Á., Benczúr L. \& Kis Gy. (2017a): A vallomások igazságtartamát meghamisítók típusai és vizsgálatuk kihallgatási helyzetben - 1. rész, a meghamisító. Psychologia Hungarica Caroliensis, 4(2), 2016. pp. 27-35.

Takács Sz., Kis Gy., Makrai B., \& Liberman A. (2017.): Tipológiákhoz tartozás varianciaanalízis alkalmazásával, LVA hangelemzés vertikális vizsgálata. Psychologia Hungarica Caroliensis, 4(2), 2016. pp. 79-93.

Kis Gy., Füzes N., Mátay G., Pusker M., Makrai, B., Czabán, Cs., \& Takács, Sz. (2017e): Újfajta szivárgások leírása a vallomások során, videófelvételek elemzésével. Psychologia Hungarica Caroliensis, 4(2), 2016. pp. 60-78. 